\title{
GMR
}

\section{Bovine dopamine receptors DRD1, DRD4, and DRD5: genetic polymorphisms and diversities among ten cattle breeds}

\author{
A.M. Sifuentes-Rincón' ${ }^{1}$, A.G. Trejo-Tapia' ${ }^{1}$, R.D. Randel ${ }^{2}$, P. Ambriz-Morales ${ }^{1}$ \\ and G.M. Parra-Bracamonte ${ }^{1}$ \\ ${ }^{1}$ Centro de Biotecnología Genómica-Instituto Politécnico Nacional, \\ Colonia Narciso Mendoza, Reynosa, Tamaulipas, México \\ ${ }^{2}$ Texas AgriLife Research, Texas A\&M System, Overton, TX, USA \\ Corresponding author: A.M. Sifuentes-Rincón \\ E-mail: asifuentes@ipn.mx \\ Genet. Mol. Res. 15 (1): gmr.15017725 \\ Received September 25, 2015 \\ Accepted December 4, 2015 \\ Published February 19, 2016 \\ DOI http://dx.doi.org/10.4238/gmr.15017725
}

\begin{abstract}
The aim of this study was to analyze the allelic frequency distribution and segregation among breeds and/or between different cattle genetic groups of four novel single nucleotide polymorphisms of the bovine DRD1 and DRD5 genes and one reported SNP from the DRD4 gene. One hundred and nine-animals from ten different cattle breeds were genotyped and allelic frequencies for each locus were estimated. There were significant differences in the allelic frequencies $(P<0.05)$ among breeds for the DRD1 and DRD5 markers. The allelic frequencies for markers DRD1-825A $>G$ and DRD5-378C >T were also significantly different between groups differing in genetic background. Because differences in temperament have been reported between Bos taurus taurus and B. taurus indicus breeds and their crosses, further studies are needed to investigate if any association exists between described markers and cattle behavior traits.
\end{abstract}

Key words: Behavior; Genetic polymorphism; Dopamine; Temperament 


\section{INTRODUCTION}

Temperament is a behavioral condition considered in animal production as an economically relevant trait (Golden et al., 2000). Poor temperament scores in cattle are associated with reduced feed efficiency (Petherick et al., 2002), reduced meat quality (Vann, 2011), and decreased immune function (Fell et al., 1999). Temperament has been found to be a heritable trait in Bos taurus taurus (Beckman et al., 2005) and B. t. indicus (Schmidt et al., 2014).

Studies have found that differences exist in temperament between B. t. taurus and B. $t$. indicus breeds and their crosses (Grandin, 1980; Hearnshaw and Morris, 1984). At the molecular level, Lourenco-Jaramillo et al. (2012), found significantly different haplotype distributions of single nucleotide polymorphisms (SNPs) located in two key enzymes (tyrosine hydroxylase and dopamine beta-hydroxylase) for dopamine and noradrenaline production. The authors proposed that these SNPs could be related to differences in temperament related to the genetic background of cattle (Lourenco-Jaramillo et al., 2012).

Dopamine receptors (DRDs) have been proposed to be candidate genes associated with different behavioral traits in mammals (Oak et al., 2000; Marsden, 2006). They have been implicated in the regulation of feeding behavior (Lutz et al., 2001) and obesity. DRD4 has been widely studied in human and non-human species, a variable number tandem repeat and other polymorphisms in this gene have been reported in human, non-human primates (Livak et al., 1995), dogs (Ito et al., 2004), and horses (Momozawa et al., 2005).

The objective was to explore DRD1, DRD4, and DRD5 gene polymorphisms in order to identify genetic variants occurring in cattle breeds with expected different temperaments according to their genetic background (i.e., B. t. taurus and B. t. indicus).

\section{MATERIAL AND METHODS}

The investigation of genetic variation in the bovine DRD1 and DRD5 genes was performed using eleven hair samples from four different cattle breeds (three Holstein, two Charolais, three Brahman, and three Lidia). Due to the absence of complete reported nucleotide sequences for DRD4 gene, we genotyped the SNP located at intron 1 of bovine DRD4 gene previously reported by Glenske et al. (2011). DNA from these samples and an additional 199 bovine hair samples obtained from different herds and breeds (B. t. taurus: Holstein, Charolais, Simmental, Lidia, and Wagyu; B. t. indicus: Brahman, Gyr, Sardo Negro, Guzerat, and Indubrasil) located at Mexico, was isolated using the Wizard® genomic DNA purification kit (Promega Corporation, Madison, WI, USA). Primer pairs were designed using Primer Select v. 7.0.0 (Lasergene, DNASTAR, Madison, WI, USA), and sequences obtained from GenBank using accession No. NM_174042.2 (DRD1) and NM_001206629.1 (DRD5). Bidirectional sequencing was achieved using the BigDye® Terminator procedure and an ABI PRISM 3100 Genetic Analyzer DNA sequencer (Applied Biosystems, Foster City, CA, USA). Sequences were aligned with Clustal X v. 2.0.8 (Larkin et al., 2007).

For genotyping, five SNPs were designed. Polymerase chain reaction (PCR) amplifications were performed in $25 \mu \mathrm{L}$ on a MJ Research Thermocycler. The reaction mixes comprised 20-100 ng genomic DNA, 1.5 or $2.5 \mathrm{mM} \mathrm{MgCl}_{2}, 0.1 \mu \mathrm{M}$ of each primer, $0.4 \mathrm{mM}$ dNTPs and $2.5 \mathrm{U}$ Go Taq polymerase (Promega Corporation, Madison, WI, USA). A touchdown method was used with the amplification profile of an initial denaturation step of $95^{\circ} \mathrm{C}$ for $10 \mathrm{~min}$, five three-step cycles of $45 \mathrm{~s}$ at $95^{\circ} \mathrm{C}, 45 \mathrm{~s}$ at $68^{\circ} \mathrm{C}$ (the temperature was reduced $2^{\circ} \mathrm{C}$ each cycle), then twenty five cycles of 45 $\mathrm{s}$ at $95^{\circ} \mathrm{C}, 45 \mathrm{~s}$ at $65^{\circ} \mathrm{C}$ and finally one cycle of $45 \mathrm{~s}$ at $72^{\circ} \mathrm{C}$. PCR fragments were separated by electrophoresis in a $1.5 \%$ agarose gel, stained with SYBR Gold and visualized by UV irradiation. 
After PCR, digestion reactions were done following the manufacturer protocol for each enzyme and digestion fragments were analyzed on a $4 \%$ Nusieve $^{\mathrm{TM}}$ (Lonza, Rockland, ME, USA) agarose gel.

The observed allelic frequencies were compared with the expected frequencies based on the Hardy-Weinberg equilibrium, using GENEPOP v. 4.0.10 (Rousset, 2008).

A principal components analysis was used to illustrate the influence of the alleles on the ten breeds using InfoGen (Balzarini and Di Rienzo, 2013).

\section{RESULTS AND DISCUSSION}

A total of four SNPs were detected: in the DRD1 gene, one transition A>G located at position 825 of the reported coding sequence was found, while in the DRD5 gene two transitions C>T and one transversion $\mathrm{G}>\mathrm{C}$ were identified at positions $\mathrm{nt} 378$, nt822, and nt484, respectively. With the exception of the transition DRD5-484C $>\mathrm{T}$, all changes were synonymous. Transition $484 \mathrm{C}>\mathrm{T}$ produces an amino acidic change of aspartic acid to histidine at position 162 of the predicted DRD5 protein. Apart from the value as a candidate marker, the DRD5-484C > T represents a polymorphism with potential functional effects. Allele frequencies for each locus were estimated for the ten breeds tested, as well as for groups of breeds representing the genetic backgrounds of B. $t$. taurus and $B$. $t$. indicus (Table 1). There were significant differences in the allelic frequencies $(P<0.05)$ among breeds for the DRD1 and DRD5 markers. Allele frequencies for markers DRD1-825A $>G$ and DRD5-378C > T were also found to be significantly different between groups of different genetic background. Subspecies-specific allele distributions of markers DRD1-825A>G, DRD5-378C>T, and DRD5-822T>C were observed between the ten breeds (Figure 1).

There are no descriptions in the literature of DRD4 allelic distribution and segregation among breeds and/or between different genetic groups of $B$. $t$. taurus or $B$. $t$. indicus. A significant observation in our study of this marker is that, even though there is no significant specific allele segregation between the genetic groups, the distribution of allelic frequencies indicated that allele $G$ was the most frequent in the B. $t$. indicus breeds, while allele T was most frequent in $B$. $t$. taurus breeds. This distribution pattern is interesting from a phenotypic point of view because Glenske et al. (2011) found that genotype TT was associated with lower curiosity scores in the German Angus breed. Curiosity is a trait related with social behavior including novelty seeking (Momozawa et al., 2005). Genetic polymorphisms in the DRD4 gene across human and non-human species have been proposed as candidates influencing temperament through the novelty-seeking trait (Ebstein et al., 1996). It is important to assess the influence of the novelty seeking trait on productive performance in cattle, in order to confirm the usefulness of this marker as a management tool.

Genetic diversity previously reported by Haegeman et al. (2003) for the DRD1 and DRD5 genes is similar to that found in our study; they also found one transition at DRD1 and five changes in DRD5. None of the reported SNPs were identified as polymorphic in our 210-studied samples. Haegeman et al. (2003) also reported the allelic frequencies across eleven European breeds and found discrepancies between the Belgian blue beef breed and the other breeds, but no phenotypic inferences were discussed.

We have demonstrated that the novel SNPs identified for the DRD1 and DRD5 genes show specific patterns of allelic segregation between breeds and genetic groups. Even if the allelic distribution found in this study are due to the population structure and/or to their evolutionary history, the current development of large-scale studies aimed at analysis of genetic variation between genetic groups has increased interest in identification of targets for positive selection among and within genetic groups. In cattle populations, there are situations in which promoted and directed genetic variability, such as breed formation and artificial selection, can enhance performance and productivity. 
A.M. Sifuentes-Rincón et al.

Table 1. Allelic frequencies of SNPs located at bovine dopamine receptors in ten cattle breeds.

\begin{tabular}{|c|c|c|c|c|c|c|c|}
\hline SNP marker & No. & Breed & Genetic background & $\mathrm{A}$ & $\mathrm{C}$ & $\mathrm{G}$ & $T$ \\
\hline \multirow[t]{12}{*}{ DRD1-825 A>G } & 23 & Charolais & B.t.taurus & 0.81 & - & 0.18 & - \\
\hline & 23 & Simmental & B.t.taurus & 0.70 & - & 0.30 & - \\
\hline & 12 & Lidia & B.t.taurus & 0.54 & - & 0.46 & - \\
\hline & 10 & Holstein & B.t.taurus & 0.66 & - & 0.34 & - \\
\hline & 25 & Wagyu & B.t.taurus & 0.47 & - & 0.53 & - \\
\hline & 22 & Brahman & B.t. indicus & 0.68 & - & 0.31 & - \\
\hline & 25 & Sardo Negro & B.t. indicus & 0.39 & - & 0.61 & - \\
\hline & 15 & Guzerat & B.t. indicus & 0.46 & - & 0.54 & - \\
\hline & 25 & Gyr & B.t. indicus & 0.49 & - & 0.51 & - \\
\hline & 19 & Indubrasil & B.t. indicus & 0.38 & - & 0.62 & - \\
\hline & 93 & B.t.taurus & & 0.75 & - & 0.24 . & - \\
\hline & 106 & B. t. indicus & & 0.54 & - & 0.45 & - \\
\hline \multirow[t]{13}{*}{ DRD4 } & 23 & Charolais & B.t.taurus & - & - & 0.57 & 0.42 \\
\hline & 23 & Simmental & B.t.taurus & - & - & 0.49 & 0.51 \\
\hline & 12 & Lidia & B.t.taurus & - & - & 0.48 & 0.52 \\
\hline & 10 & Holstein & B.t.taurus & - & - & 0.50 & 0.50 \\
\hline & 25 & Wagyu & B.t.taurus & - & - & 0.53 & 0.47 \\
\hline & 22 & Brahman & B.t. indicus & - & - & 0.74 & 0.24 \\
\hline & 25 & Sardo Negro & B.t. indicus & - & - & 0.81 & 0.19 \\
\hline & 15 & Guzerat & B.t. indicus & - & - & 0.67 & 0.33 \\
\hline & 25 & Gyr & B.t. indicus & - & - & 0.63 & 0.37 \\
\hline & 19 & Indubrasil & B.t. indicus & - & - & 0.72 & 0.28 \\
\hline & 93 & B.t. taurus & & - & - & 0.27 & 0.72 \\
\hline & 106 & B.t. indicus & & - & - & 0.67 & 0.32 \\
\hline & 23 & Charolais & B.t.taurus & - & 1.00 & - & 0.00 \\
\hline \multirow[t]{11}{*}{ DRD5-378C>T } & 23 & Simmental & B.t.taurus & - & 1.00 & - & 0.00 \\
\hline & 12 & Lidia & B.t.taurus & - & 1.00 & - & 0.00 \\
\hline & 10 & Holstein & B.t.taurus & - & 1.00 & - & 0.00 \\
\hline & 25 & Wagyu & B.t.taurus & - & 1.00 & - & 0.00 \\
\hline & 22 & Brahman & B.t. indicus & - & 0.52 & - & 0.48 \\
\hline & 25 & Sardo Negro & B.t. indicus & - & 0.39 & - & 0.61 \\
\hline & 15 & Guzerat & B.t. indicus & - & 0.63 & - & 0.37 \\
\hline & 25 & Gyr & B.t. indicus & - & 0.60 & - & 0.30 \\
\hline & 19 & Indubrasil & B.t. indicus & - & 0.41 & - & 0.59 \\
\hline & 93 & B.t.taurus & & - & 1.00 & - & 0.00 \\
\hline & 106 & B.t. indicus & & - & 0.52 & - & 0.47 \\
\hline \multirow[t]{12}{*}{ DRD5-484C>T } & 23 & Charolais & B.t.taurus & - & 0.70 & - & 0.30 \\
\hline & 23 & Simmental & B.t.taurus & - & 0.49 & - & 0.51 \\
\hline & 12 & Lidia & B. t. taurus & - & 0.39 & - & 0.61 \\
\hline & 10 & Holstein & B.t.taurus & - & 0.42 & - & 0.58 \\
\hline & 25 & Wagyu & B.t.taurus & - & 0.62 & - & 0.38 \\
\hline & 22 & Brahman & B.t. indicus & - & 0.64 & - & 0.36 \\
\hline & 25 & Sardo Negro & B.t. indicus & - & 0.59 & - & 0.41 \\
\hline & 15 & Guzerat & B.t. indicus & - & 0.48 & - & 0.52 \\
\hline & 25 & Gyr & B.t. indicus & - & 0.34 & - & 0.66 \\
\hline & 19 & Indubrasil & B.t. indicus & - & 0.63 & - & 0.37 \\
\hline & 93 & B.t. taurus & & - & 0.72 & - & 0.27 \\
\hline & 106 & B.t. indicus & & - & 0.60 & - & 0.39 \\
\hline \multirow[t]{12}{*}{ DRD5-822T>C } & 23 & Charolais & B.t. taurus & - & 0.60 & - & 0.40 \\
\hline & 23 & Simmental & B.t.taurus & - & 0.44 & - & 0.56 \\
\hline & 12 & Lidia & B.t.taurus & - & 0.48 & - & 0.52 \\
\hline & 10 & Holstein & B.t.taurus & - & 0.61 & - & 0.39 \\
\hline & 25 & Wagyu & B.t.taurus & - & 0.58 & - & 0.42 \\
\hline & 22 & Brahman & B.t. indicus & - & 0.82 & - & 0.16 \\
\hline & 25 & Sardo Negro & B.t. indicus & - & 0.60 & - & 0.40 \\
\hline & 15 & Guzerat & B.t. indicus & - & 0.67 & - & 0.33 \\
\hline & 25 & Gyr & B.t. indicus & - & 0.73 & - & 0.27 \\
\hline & 19 & Indubrasil & B.t. indicus & - & 0.66 & - & 0.34 \\
\hline & 93 & B.t. taurus & & - & 0.57 & - & 0.43 \\
\hline & 106 & B.t. indicus & & - & 0.76 & - & 0.24 \\
\hline
\end{tabular}




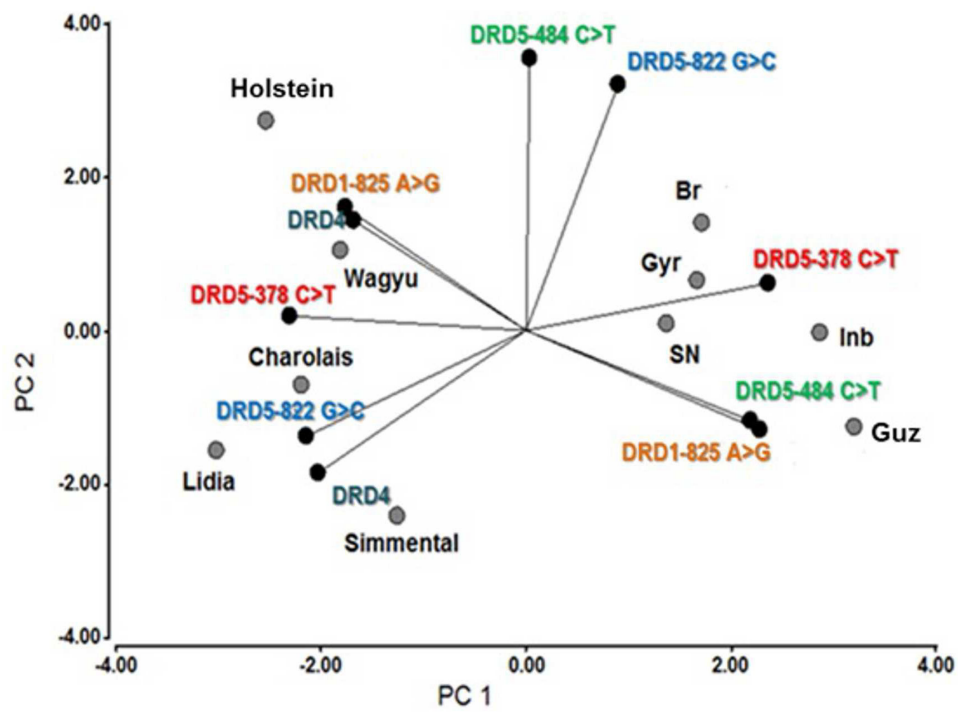

Figure 1. Principal components PC1 and PC2 from all SNPs. Taurine breeds, remain separated from indicine. (Br: Brahman, NS: Sardo Negro, Ind: Indobrasil, Guz: Guzerat) breeds.

\section{Conflicts of interest}

The authors declare no conflict of interest.

\section{ACKNOWLEDGMENTS}

The authors thank the different herd owners for supporting the cattle sampling. Research supported by grants FOMIX-TAMAULIPAS \#177460 and SIP-IPN \#20151289.

\section{REFERENCES}

Balzarini MG and Di Rienzo JA (2013). InfoGen versión 2013. FCA, Universidad Nacional de Córdoba, Argentina. http://www. info-gen.com.ar.

Beckman D, Speidel S, Brigham B, Garrick D, et al. (2005). Genetic parameter estimates for docility in Limousin cattle. Proc. Western Section Am. Soc. Anim. Sci. 56: 109-111.

Ebstein RP, Novick O, Umansky R, Priel B, et al. (1996). Dopamine D4 receptor (D4DR) exon III polymorphism associated with the human personality trait of Novelty Seeking. Nat. Genet. 12: 78-80. http://dx.doi.org/10.1038/ng0196-78

Fell LR, Colditz IG, Walker KH and Watson DL (1999). Associations between temperament, performance and immune function in cattle entering a commercial feedlot. Aust. J. Exp. Agric. 39: 795-802. http://dx.doi.org/10.1071/EA99027

Glenske K, Prinzenberg EM, Brandt H, Gauly M, et al. (2011). A chromosome-wide QTL study on BTA29 affecting temperament traits in German Angus beef cattle and mapping of DRD4. Animal 5: 195-197. http://dx.doi.org/10.1017/ $\underline{\text { S1751731110001801 }}$

Golden BL, Garrick DJ, Newman S and Enns RM (2000). Economically relevant traits a framework for the next generation of EPDs. Proceedings - Beef Improvement Federation 32nd Annual Research Symposium, Raleigh NC, 2-13.

Grandin T (1980). Livestock behavior as related to handling facilities design. Int. J. Study Anim. Probl. 1: $33-52$.

Haegeman A, Williams JL, Law A, Van Zeveren A, et al. (2003). Characterization and mapping of bovine dopamine receptors 1 and 5. Anim. Genet. 34: 290-293. http://dx.doi.org/10.1046/j.1365-2052.2003.00994.x

Hearnshaw $\mathrm{H}$ and Morris CA (1984). Genetic and environmental effects on a temperament score in beef cattle. Aust. J. Agric. Res. 35: 723-733. http://dx.doi.org/10.1071/AR9840723 
Ito $\mathrm{H}$, Nara H, Inoue-Murayama M, Shimada MK, et al. (2004). Allele frequency distribution of the canine dopamine receptor D4 gene exon III and I in 23 breeds. J. Vet. Med. Sci. 66: 815-820. http://dx.doi.org/10.1292/jvms.66.815

Larkin MA, Blackshields G, Brown NP, Chenna R, et al. (2007). Clustal W and Clustal X version 2.0. Bioinformatics 23: 29472948. http://dx.doi.org/10.1093/bioinformatics/btm404

Livak KJ, Rogers J and Lichter JB (1995). Variability of dopamine D4 receptor (DRD4) gene sequence within and among nonhuman primate species. Proc. Natl. Acad. Sci. USA 92: 427-431. http://dx.doi.org/10.1073/pnas.92.2.427

Lourenco-Jaramillo DL, Sifuentes-Rincón AM, Parra-Bracamonte GM, de la Rosa-Reyna XF, et al. (2012). Genetic diversity of tyrosine hydroxylase (TH) and dopamine b-hydroxylase (DBH) genes in cattle breeds. Genet. Mol. Biol. 35: 435-440. http://dx.doi.org/10.1590/S1415-47572012000300009

Lutz TA, Tschudy S, Mollet A, Geary N, et al. (2001). Dopamine D(2) receptors mediate amylin's acute satiety effect. Am. J. Physiol. Regul. Integr. Comp. Physiol. 280: R1697-R1703.Marsden CA (2006). Dopamine: the rewarding years. Br. J. Pharmacol. 147 (Suppl 1): S136-S144. http://dx.doi.org/10.1038/sj.bjp.0706473

Momozawa Y, Kusunose R, Kikusui T, Takeuchi Y, et al. (2005). Assessment of equine temperament questionnaire by comparing factor structure between two separate surveys. Appl. Anim. Behav. Sci. 92: 77-84. http://dx.doi.org/10.1016/j. applanim.2004.11.006

Oak JN, Oldenhof J and Van Tol HH (2000). The dopamine D(4) receptor: one decade of research. Eur. J. Pharmacol. 405: 303-327. http://dx.doi.org/10.1016/S0014-2999(00)00562-8

Petherick JC, Holroyd RG, Doogan VJ and Venus BK (2002). Productivity, carcass and meat quality of lot-fed Bos indicus cross steers grouped according to temperament. Aust. J. Exp. Agric. 42: 389-398. http://dx.doi.org/10.1071/EA01084

Rousset F (2008). genepop'007: a complete re-implementation of the genepop software for Windows and Linux. Mol. Ecol. Resour. 8: 103-106. http://dx.doi.org/10.1111/j.1471-8286.2007.01931.x

Schmidt SE, Neuendorff DA, Riley DG, Vann RC, et al. (2014). Genetic parameters of three methods of temperament evaluation of Brahman calves. J. Anim. Sci. 92: 3082-3087. http://dx.doi.org/10.2527/jas.2013-7494

Vann RC (2011). Relationships between carcass quality and temperament in beef cattle. Proceedings - Beef Improvement Federation 43rd Annual Research Symposium, Raleigh NC, 69-72. 